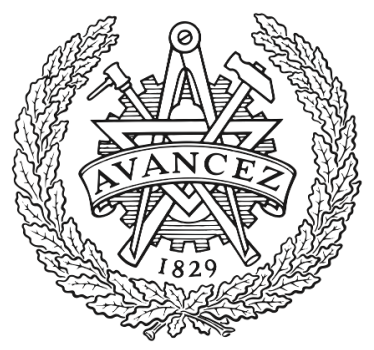

CHALMERS

UNIVERSITY OF TECHNOLOGY

\title{
Appraisal, preaching and the religious other: The rhetorical appropriation of interreligious positions in sermonic discourse
}

Downloaded from: https://research.chalmers.se, 2023-04-26 12:58 UTC

Citation for the original published paper (version of record):

Malmström, H. (2018). Appraisal, preaching and the religious other: The rhetorical appropriation of interreligious

positions in sermonic discourse. International Journal of Practical Theology, 22(1): 40-57.

http://dx.doi.org/10.1515/ijpt-2017-0016

N.B. When citing this work, cite the original published paper. 
Hans Malmström*

\section{Appraisal, Preaching and the Religious Other: The Rhetorical Appropriation of Interreligious Positions in Sermonic Discourse}

https://doi.org/10.1515/ijpt-2017-0016

Abstract: This paper explores preachers' deployment of Appraisal (affect, judgement, appreciation, and dialogic engagement) in preaching on interreligious themes. Adopting a comparative discourse analysis, the paper investigates two American sermons representing diametrically opposed theological responses to other religions, a pluralist sermon in the Unitarian Universalist tradition and an exclusivist sermon in the biblical-evangelical tradition. An analysis of the two preachers' Appraisal choices reveals two distinct Appraisal profiles. A discussion is then offered demonstrating how Appraisal is conducive to the appropriation and conservation of a specific interreligious persona during preaching.

Keywords: Appraisal, language, interreligious dialogue, preaching, exclusivism, pluralism

Zusammenfassung: Der Beitrag untersucht, inwiefern Prediger/innen bei der Auseinandersetzung mit interreligiösen Themen beurteilend oder den Wert des Gegenüber ermessend verfahren. Hierzu dient eine komparative Diskursanalyse zweier amerkanischer Predigten, die auf theologisch entgegengesetzte Weise andere Religionen thematisieren. Der Autor zeigt auf, wie solches Ermessen (“Appraisal”) bei der Aneignung einer interreligiösen Handlungsrolle für das Predigen dienlich sein kann.

Stichwörter: Appraisal, Sprache, interreligiöser Dialog, Predigt, Exklusivismus, Pluralismus

Note: This paper was written when the author was a visiting scholar at the Center for the Study of World Religions, Harvard Divinity School.

*Corresponding author: Dr. Hans Malmström, Chalmers University of Technology, Department of Communication and Learning in Science, Division for Language and Communication, Hörsalsvägen 2, 412 96, Gothenburg, SWEDEN, E-Mail: mahans@chalmers.se 


\section{Introduction}

Comparative theologian Marianne Moyaert (2016) notes how much research work in the overlapping areas of comparative theology and theology of interreligious dialogue tends to privilege the study of (often ancient) texts. ${ }^{1}$ To counter this situation, she suggests that our scholarly scope needs to be broadened and pay more attention also to additional empirical perspectives on contemporary liturgical practices. According to Moyaert, such a research agenda could offer new dimensions to fundamental questions addressed by several different theological disciplines.

The present interdisciplinary study heeds this call for a practical and empirical turn and reconciles linguistic discourse analysis with interreligious homiletic and theology of interreligious dialogue. This is a study of Christian preaching which directly engages with dimensions of another religion (e.g. the adherents, traditions, or beliefs of another religion), adopting a discourse driven homiletic of the (inter)religious Other. A focus on sermonic-discursive interaction with other religions offers potentially novel and performative perspectives on the construction of religious otherness, adding important insights on what constitutes a theological response to other religions and the formation of an interreligious identity. ${ }^{2,3}$

The starting point, and the theoretical foundation for this study, is an argument concerning the very nature of preaching that recognizes the religious Other; such preaching, it is suggested, evokes internal, multivoiced, and transformative interreligious dialogue.

\section{A homiletic of the religious Other - internal interreligious dialogue and the construal of other religions}

Preaching on interreligious themes provides for an intriguing form of "encounter" between religions which could conceivably be viewed as internal interreligious dialogue as understood by Sallie B. King, i.e. an "internal conversation going on

1 Marianne Moyaert, "Towards a Liturgical Turn in Comparative Theology? Opportunities, Challenges, and Problems" (Annual Lecture of Comparative Theology, Harvard Divinity School, Cambridge, MA, March 16, 2016).

2 Cf. Paul F. Knitter, Introducing Theologies of Religions (Maryknoll, NY: Orbis Books, 2002).

3 Cf. Gavin D'Costa, Christianity and World Religions (Chichester, U.K.: Wiley-Blackwell, 2009). 
between two religions to which [an individual] has been exposed [...]." ${ }^{4}$ The sermon excerpt in (1) illustrates this type of preaching.

(1) Our Muslim brothers and sisters are as peace-yearning as we are and Jesus wants us to be tolerant and loving towards followers of Islam.

The preacher's naming of Muslim brothers and sisters and followers of Islam creates an interreligious dialogic space within the sermon where preachers and listeners can share an interreligious discourse. Here, listeners may listen, tacitly question, critically reflect on, and even contest the world view assumed by the interreligious discourse. This is a dialogue, in the words of Faisal Bin Abdulrahman Bin Muaammar, "about the meaning of life, through a search for meaning that investigates the foundations of religious, cultural, and ideological worldviews, as well as their constant interactions." It is appropriately labelled "internal dialogue" because it "takes place within one's own self-consciousness, stimulated by interactions with both written and oral sources of knowledge. It is a dialogue that is often invisible and inaudible because it takes place inside one's head and heart." 5

The most obvious instance of dialogue in preaching involving interreligious themes is that between preachers and listeners, where both parties "open themselves...in interchange, considering the viewpoints and trying to understand the issue from the others' point of view." 6 That dialogue, however, is nurtured by an earlier yet inevitably ongoing interaction between the preacher and the religious Other, preceding the sermon event, interaction which the preacher is inviting the listeners to share in. When that happens, an unknown number of additional dialogues are initiated between the listeners and an infinite number of additional sources as such Others are called forth from the listener's mind. As the listener consciously or subconsciously engages these additional voices they come to bear directly on the conversation involving the religious other, creating a dynamic

\footnotetext{
4 Sallie B. King, "Interreligious Dialogue," in The Oxford Handbook of Religious Diversity, ed. Chad Meister (Oxford: Oxford University Press, 2011), 102.

5 Faisal Bin Abdulrahman Bin Muaammar, "Agree to Differ in Matters of Ultimate Concern: Religious Diversity and Interreligious Dialogue,” in UNESCO: Agree to Differ (Paris: United Nations Educational, Scientific and Cultural Organization/Tudor Rose, 2015), 48.

6 Ronald J. Allen, "Preaching as Mutual Critical Correlation through Conversation," in Purposes of Preaching, ed. Jana Childers (St. Louis: Chalice Press, 2004), 3. A conception of preaching as dialogue/conversation is maintained in numerous contemporary works in homiletics (see e.g. David J. Lose, "Preaching as Conversation," in Under the Oak Tree: The Church as Community of Conversation in a Conflicted and Pluralistic World, ed. Ronald J. Allen, John S. McClure, and O. Wesley Allen, Jr. (Eugene: Wipf and Stock, 2013), 71-92; O. Wesley Allen, Jr., The Homiletic of All Believers (Louisville, KY: Westminster John Knox Press, 2005).
} 
multivoiced conversational matrix. Allen stresses how, together, the preacher and the listeners may draw on and appropriate "the Bible...elements of Christian history, doctrine, and practice; voices in the broader Christian community and contributions from the wider world...written materials, artistic expressions, political and social events or other phenomena." It is conceivable that the conversational strata bearing on the internal conversation (see Figure 1) are influenced also by the moral foundations underlying the particular denomination, such that particular religious-moral ideologies or worldviews impinge on the conversation. ${ }^{8}$

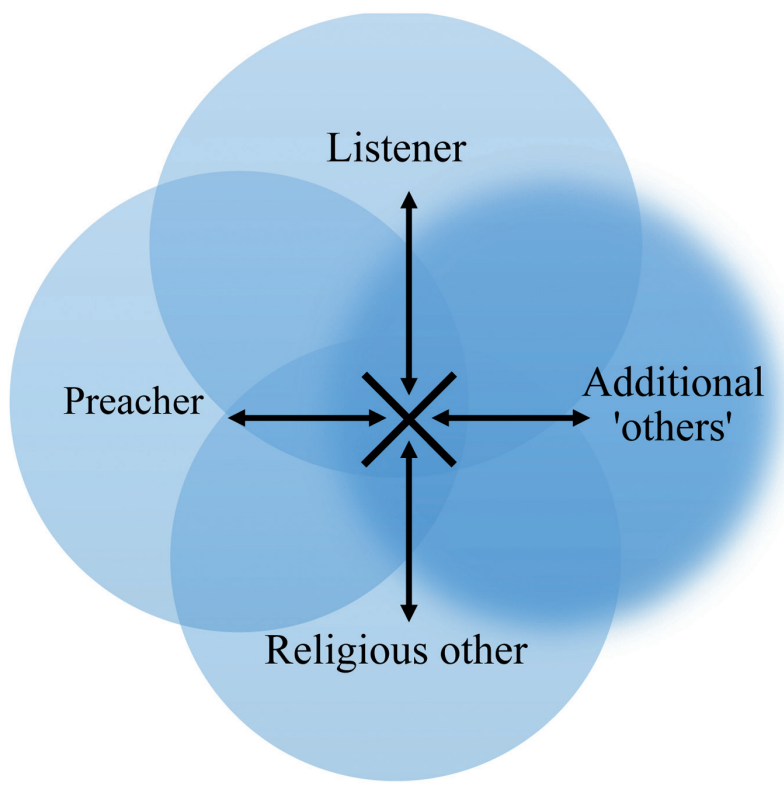

Fig. 1: Multivoiced preaching conversation reflective of internal interreligious dialogue.

7 Allen, Preaching (n. 6), 5.

8 Jonathan Haidt, The Righteous Mind (New York: Vintage Books, 2013), 146. While moral foundations theory has argued most strongly for a correlation between moral foundations and political ideologies, it does not seem implausible to propose a similar correlation between moral foundations and interreligious identity. On this view, particular narratives, sets of values, virtues and norms relating to the interreligious Other would be sustained within a particular denomination and directly affect both the conditions for interreligious dialogue, and the internal dialogue itself as the conversations develop during and beyond the sermon. 
The interpretation of Figure 1 rests on the assumption that no party to these conversations is just a conversational object; a possible linguistic objectification does not preclude conversational subjectification. At the epicenter of these conversations appears a promising dialogic nexus; this highlights the locus of the internal interreligious dialogue, where an interdiscursive link can be established between religious traditions, creating for the listeners "their own conversation between the secular and the religious...[giving] birth to sermons brought into being by the individual members of the congregation...as they disperse to dialogue with and act in the secular world." Thus, in the interreligious sermon, a real internal dialogue (or "multilogue") involving preacher-listeners-others is initiated, but any engagement (listening, questioning, arguing, struggling, reflecting etc.) with the religious other does not stop there, rather it continues beyond the confines of the sermonic experience, and may often have transformative implications.

When preachers and listeners together transcend their own religious tradition and reach out to other religions in this way, the sermon becomes a dynamic locus for "worldviews argued through to significant and potentially transformative conclusions." 10 This transcendence of traditions can have a profound impact on the preacher as well as the listeners. Yarbrough describes the preacher's experience: "We cannot preach in the way we might have before that transformational experience. The impact of the border crossing experience of interreligious dialogue and encounter changes the preacher." "McClure notes something similar in his model of Other-wise preaching: "The preacher begins to find new ways to understand himself or herself in relation to others." ${ }^{\prime 2}$ Conceivably, such transformation carries over to the listeners as they too are touched by the other's voice resonating through the sermon as it blends with other strata in the internal conversation.

Mara Brecht proposes three possible "forms" of transformation as a result of engaging in interreligious dialogue: the transformation of recommitting to one's tradition; the transformation of double religious belonging or hybridity; and the transformation of conversion. ${ }^{13}$ Assuming that Brecht is correct, interreligious

9 Allen, The Homiletic (n. 6), 11.

10 Paul Hedges, Controversies in Interreligious Dialogue and the Theology of Religions (London: SCM Press, 2010), 63.

11 Denise Yarbrough, "Practicing the Theology of Companionship: Preaching an Interreligious Gospel," in Preaching and the Theological Imagination, ed. Zachary Guiliano and Cameron E. Partridge (New York: Peter Lang, 2015), 198.

12 John S. McClure, Other-Wise Preaching (St. Louis: Chalice Press, 2001), 136.

13 Mara Brecht, Virtue in Dialogue: Belief, Religious Diversity, and Women's Interreligious Encounter (Eugene: Pickwick, 2014), chapter 8. Brecht's treatment of transformation is very much an argument between Paul Ricoeur on the one hand (and his notion of "second naiveté"), a 
preaching is “high-stakes" religious discourse where preachers' and listeners' confessional identities are projected against a background of dialogue between religions where no voice is privileged; neither preacher nor listener can independently determine the outcome of the internal interreligious dialogue, but the sermonic event can affect the dialogue significantly. This brings us to the contribution of this paper and the focus on the rhetorical dimension of evaluation.

When preachers construe other religions, for themselves and for their listeners, these construal operations evoke various, often highly fragmented, notions of religious Otherness which might be adopted by sermon listeners and can have considerable impact on their attitudes towards other religions (how listeners choose to engage with these voices of the religious Other). Central to the formation and maintenance of preacher- and listener attitudes in this context of interreligiousness is evaluative construal, i.e. preachers' use of language to, among other things, "approve and disapprove, enthuse and abhor, applaud and criticize [and to] construe for themselves particular [...] identities or personae." ${ }^{14}$ To this end, preachers' use of evaluative language signals a great deal about the value systems that underlie the construction of their own individual confessional identity and interpersonal dispositions.

\section{Claim and objective}

The claim in this paper is this: the way preachers deploy evaluative language in relation to dimensions of other religions is consistent with their theological (and ideological) response to other religions, i.e. their disposition to what is commonly referred to as exclusivist, inclusivist, particularist, or pluralist religious identities, which are in turn nurtured by, e.g., a particular moral matrix. ${ }^{15}$, 16 The primary objective of the paper is to offer a demonstration of how evaluative language is conducive to entertaining an interreligious preaching identity. An investigation of preachers' use of evaluation during preaching on interreligious themes will suggest how interreligious interpersonal positions are rhetorically appropriated,

strengthening of the listeners "domestic" religious beliefs, and Perry Schmidt-Leukel (transformation by integration) on the other, a reshaping of the individual listener's religious beliefs, which may involve a spectrum from the formation of a multireligious or syncretic identity (hybridity), to complete acceptance of the other religious tradition as one's own (conversion).

14 J. R. Martin and P. R. R.White, The Language of Evaluation (Basingstoke: Palgrave Macmillan, 2005), 1.

15 Cf. Hedges, Controversies (n. 10), ch. 1-3.

16 Haidt, Righteous Mind (n. 8), 145. 
thereby furthering our knowledge of what constitutes an exclusivist, inclusivist, particularist, and pluralist identity, and how such an identity can be entertained as a critical element in the dialogic encounter with listeners in the sermon. The present study is limited to a study of preaching reflecting a pluralist theological response and an exclusivist theological response.

\section{Data and methods}

This is a qualitative case study of two diametrically opposed theological responses to religious Otherness during two preaching events. One represents a pluralist position and one represents an exclusivist position. Exclusivism and pluralism should be seen as nothing but a convenient shorthand for describing two (mostly) conflicting kinds of Christian identity constituted by a set of crude theological-response descriptors. With that proviso, Table 1 provides some characteristics observable for exclusivism and pluralism respectively.

Table 1: Overview of main tenets of exclusivism and pluralism. ${ }^{17}$

\begin{tabular}{|c|c|c|}
\hline & The exclusivist... & The pluralist... \\
\hline ...view on Christianity & $\begin{array}{l}\text { Christianity is central and } \\
\text { superior to other religions. }\end{array}$ & $\begin{array}{l}\text { Christianity is on a par with } \\
\text { other faith traditions and } \\
\text { thus not superior. }\end{array}$ \\
\hline ...view on salvation & $\begin{array}{l}\text { Salvation is possible only on the } \\
\text { basis of Christ's redeeming } \\
\text { actions and our faith in him. }\end{array}$ & $\begin{array}{l}\text { Salvation is possible in a } \\
\text { multitude of ways. }\end{array}$ \\
\hline $\begin{array}{l}\text {... view on epistemic } \\
\text { confidence in teachings of the } \\
\text { denomination }\end{array}$ & Firm. & Flexible. \\
\hline $\begin{array}{l}\text {...view on the Bible vs. sacred } \\
\text { writings in other religions }\end{array}$ & $\begin{array}{l}\text { Strict adherence; the Bible is } \\
\text { God's word intended exclusively } \\
\text { for his Christian community; } \\
\text { proclamation is foregrounded. }\end{array}$ & $\begin{array}{l}\text { To be read in light of } \\
\text { experience with other } \\
\text { faiths; hermeneutics is } \\
\text { foregrounded. }\end{array}$ \\
\hline
\end{tabular}

17 Sources: James Moreland and William Craig, Philosophical Foundations for a Christian Worldview (Downers Grove: Inter Varsity Press, 2003); Hedges, Controversies (n. 10); Knitter, Introducing (n. 2); Hick, “Religious Pluralism” (n. 27). 
Table 1: (continued)

\begin{tabular}{lll}
\hline & The exclusivist... & The pluralist... \\
\hline ...view on other religions & $\begin{array}{l}\text { Religions are fundamentally } \\
\text { different/inconsistent/incompati- } \\
\text { ble; other religions represent } \\
\text { perverted beliefs of no value to } \\
\text { Christians. }\end{array}$ & $\begin{array}{l}\text { Differences in tradition are } \\
\text { not barriers; Christians } \\
\text { seligions. }\end{array}$ \\
& $\begin{array}{ll}\text { People of other religions are } \\
\text { deceived or lost (even doomed). }\end{array}$ & $\begin{array}{l}\text { People of any religion } \\
\text { deserve our utmost respect. }\end{array}$ \\
\hline r..view of adherents of other & $\begin{array}{ll}\text { No dialogue; evangelization } \\
\text { foligions }\end{array}$ & Dialogue is central. \\
\hline ...view on dialogue & Based in social-conservatism. & Based in liberalism. \\
\hline ...view on morality & & \\
\hline
\end{tabular}

Sermon sample $A$ is from a sermon entitled "Acts of Faith: Interreligious Engagement as Spiritual Practice." The sermon was preached in the First Unitarian Church in Chicago on June 24, 2012. The church describes itself as

\begin{abstract}
...a diverse community of life-long learning and growing. We have no creed, but are joined together in the spirit of love and the light of our mission and vision... We are intentionally inclusive, embracing and appreciating people of every age, race, culture, gender, sexual orientation, ability, and economic circumstance. We welcome people from all religious backgrounds and beliefs and we support you in your seeking and growing.
\end{abstract}

The preacher is Nicholas Cable, at the time a Master of Divinity student at Chicago Theological Seminary, where he was studying to become a Unitarian Universalist congregational minister. This sermon adopts a typical Unitarian Universal approach to interreligious relations, is truly pluralistic, and firmly based on liberal moral values, e.g. "kindness, tolerance, magnanimity, community spirit, the defense of the weak against the powerful, love of learning [from others], freedom of belief [...]."18

Sermon sample B is from a sermon entitled "Islam in the light of the Bible", preached in two parts on consecutive Sundays (10 May and 17 May) in 2015. The preacher is Steven L. Anderson, a pastor in the independent Faithful Word Baptist Church, Tempe, Arizona. ${ }^{19}$ The church provides the following brief statement on their website:

18 Garrison Keillor, Homegrown Democrat: A Few Plain Thoughts from the Heart of America (New York: Viking, 2004), 20.

19 It should be stressed that Faithful Word Baptist Church is an independent Baptist Church. 
We are a local New Testament church reaching the Phoenix area with the Gospel of Jesus Christ. Don't expect anything contemporary or liberal. We are an old-fashioned, independent, fundamental, King James Bible only, soul-winning Baptist church.

Anderson is well-known within and outside the US for his biblical-evangelical preaching (audio recordings of his sermons have been downloaded more 12 million times), which is frequently colored by an explicit "anti-other-than-Christian" approach. This sample represents an extreme exclusivist approach, based in typical social-conservative moral principles, e.g. the defense of "traditional" values, recognition of authority, loyalty, and sanctity of institutions (broadly speaking, but including e.g. the church). ${ }^{20}$

Sample A was transcribed in full, and an existing transcription of sermon sample B was checked for accuracy and amended where necessary. ${ }^{21}$ Specific sections of the sermons were then selected for a detailed discourse analysis involving close reading and categorization of evaluative language (in part following a four-step procedure set out in Eggins and Slade: identifying evaluative expressions; classifying evaluative expressions; summarizing evaluative choices; and interpreting evaluative patterns). ${ }^{22}$ For both samples, the opening section (approx. 750 words of text) was subject to a detailed analysis from beginning to end. Added to this analysis were excerpts of the sermon that explicitly name or reference other religion(s) or talk about the relationship between religions.

\section{Analytical framework - Appraisal Theory}

In order to demonstrate how evaluative language is conducive for entertaining an interreligious preaching identity this study adopts Appraisal Theory, ${ }^{23}$ "a particular approach to exploring, describing and explaining the way language is used to evaluate, to adopt stances, to construct textual personas and to manage interper-

20 Haidt, Righteous Mind (n. 8), ch. 12.

21 Both sermons are available online. Sermon by Nicolas Cable: http://uucw.org/worship/ser mons/sermon/76-acts-of-faith-interreligious-engagement-as-spiritual-practice, accessed February 1, 2018; sermon by Steven L. Anderson: https://www.youtube.com/watch?v=ZyizRJwnIkQ, accessed February 1, 2018.

22 Suzanne Eggins and Diana Slade, Analysing Casual Conversation (London: Equinox, 2005).

23 Cf. J. R. Martin and David Rose, Working with Discourse: Meaning beyond the Clause (London: Continuum, 2003); P. R. R. White, "Praising and Blaming, Applauding and Disparaging-Solidarity, Audience Positioning and the Linguistic of Evaluation Disposition," in Handbook of Interpersonal Communication, ed. Gerd Antos and Eija Ventola (Amsterdam: De Gruyter Mouton, 2008), 567-594. 
sonal positionings and relationships." ${ }^{24}$ Appraisal Theory is a linguistic framework firmly integrated within Systemic Functional Linguistics, ${ }^{25}$ where appraisal is seen as integral to the interpersonal metafunction of communication, i.e. as relating to speakers' social interaction with each other through language. Importantly, the framework assumes that "there is something significant in terms of interpersonal positioning when a [speaker] chooses one [appraisal mode] rather than another." 26 In this study, the primary focus is appraisal along two dimensions: ATTITUDE and DIALOGIC ENGAGEMENT.

Appraisal Theory operates with a tripartite subcategorization of ATTITUDE where the first is that of AFFECT. АFFECT is expressed with reference to preachers' positive or negative (more rarely neutral) affectual position, i.e. their emotional response to people, objects or states of affairs (e.g. God's kindness amazes me). The second attitudinal dimension is that of JUDGEMENT, i.e. "assessment of human behavior and character by reference to ethics, morality and other systems of conventionalized or institutionalized norms" (e.g. We are called to righteousness). ${ }^{27}$ Finally, APPRECIATION is evaluation in the form of "assessment of objects, artifacts, texts, states of affairs, and processes in terms of how they are assigned value socially [...] i.e. in terms of their aesthetic qualities, their potential for harm, or benefit, their social salience, and so on" (ibid.) (e.g. This book is abominable). Lexico-grammatically, attitude along any dimension can be realized in a multitude of ways.

DIALOGIC ENGAGEMENT is concerned with the multivoicedness of discourse, how speakers engage (directly or indirectly) with voices other than their own, real or hypothetical, voices of the past, present or future. Engagement, therefore, is about the arguability of statements/propositions, language which allows preachers to anticipate whether the attitudinal position they advance might be seen as controversial or questionable by listeners or, alternatively, whether the position is presented as one with which listeners might readily agree. As Martin and White say, engagement highlights the heteroglossic-monoglossic tension in communication and is manifested during interaction by preachers' "quoting or reporting, acknowledging a possibility, denying, countering, affirming and so on" (e.g. The Bible teaches us about atonement in Romans 5.../ It seems to me that God is speaking directly to us here). ${ }^{28}$

24 Martin and White, Language (n. 14), 1.

25 M.A. K. Halliday and Christian Matthiessen, Introducing Functional Grammar (London: Hodder Arnold, 2004).

26 White, "Praising and Blaming” (n. 22), 580.

27 White, "Praising and Blaming” (n. 22), 570.

28 Martin and White, Language (n. 14), 36. 


\section{Appraisal profile - pluralist and exclusivist preaching}

In this section of the paper, a brief depiction of how appraisal is deployed and distributed in each of the samples - an appraisal profile - is offered (with partial quotations from the sermons to illustrate). While differences between the two samples are to some extent predictable - they represent polarity exemplars after all - the profile needs to be established; it is our window for understanding how appraisal choices are conducive to the formation and conservation of a specific interreligious persona (the focus of the discussion in the next section). An overview of the findings is included in Table 2.

Table 2: Patterns of appraisal: overview across the sermon samples

\begin{tabular}{lll}
\hline & Pluralist sermon & Exclusivist sermon \\
\hline Attitude & $\begin{array}{l}\text { AFFECT is foregrounded } \\
\text { throughout the sermon. }\end{array}$ & $\begin{array}{l}\text { JUDGEMENT is a salient feature } \\
\text { throughout the sermon. }\end{array}$ \\
\hline $\begin{array}{l}\text { APPRECIATION exists but is } \\
\text { limited; JUDGEMENT is } \\
\text { backgrounded. }\end{array}$ & $\begin{array}{l}\text { AFFECT and APPRECIATION exist } \\
\text { but are limited and “local.” }\end{array}$ \\
\hline & $\begin{array}{l}\text { Strong preference for inscribed } \\
\text { evaluation. }\end{array}$ & $\begin{array}{l}\text { Preference for inscribed } \\
\text { evaluation, but invoked } \\
\text { evaluation is also common. }\end{array}$ \\
\hline Dialogic engagement & $\begin{array}{l}\text { Diversely multivoiced. } \\
\text { Assertiveness and } \\
\text { tentativeness complement } \\
\text { each other discursively. }\end{array}$ & $\begin{array}{l}\text { Selectively multivoiced. } \\
\text { Preference for assertive voice. }\end{array}$ \\
& & \\
\hline
\end{tabular}

The subtype of ATTITUDE most prominently foregrounded in the pluralist sermon is AFFECT evaluation.

(2) ...there is hope. There is hope, it is in me and it is in you.

(3) ...fill our hearts with sadness

(4) ...our earth remains in a state of shock

Early APPRECIATION is expressed in the negative:

(5) We live in a precarious time in human history, countries around the world are facing economic collapse, political revolution and intense social upheaval. 
This pessimistic tone is subsequently replaced by more optimistic APPRECIATION (6) but overall APPRECIATION is less productive in this sermon than AFFECT.

(6) All of you here this morning are bright and shining symbols of the future

Significantly, only a small number of instances of JUDGEMENT were identified in the pluralist sermon and, with one exception (a critical remark about politicians) they involve positive JUDGEMENT:

(7) progressive people...

(8) ...manifest by our compassionate hands and our warm, loving hearts.

Turning from the pluralist sermon to the exclusivist sermon means, overall, turning from positive evaluation to negative evaluation. In contrast to the pluralist preacher, this preacher uses AFFECT appraisal very rarely. AFFECT is most noticeable in a single section of the sermon where, in somewhat confusing terms, the preacher's feelings towards Muslims are accounted for.

(9) I do not hate Muslims at all. In fact, I love Muslims and want them to be saved. Do I hate Mohammed? Yes. Do I hate the Quran? Yes, but I do not hate Muslim people at all. Many Christians do hate Muslims...I love Muslims...I love Arabic people, Persian people, Indonesian people, I want them to get saved. No hatred in my heart whatsoever for them. I only hate those who hate the Lord.

In terms of JUDGEMENT evaluation, there is stark contrast between the pluralist and the exclusivist sermon. Notwithstanding the exclusivist preacher's insistence that he has no desire to "anger or offend Muslims", highly reproving JUDGEMENT appears to be a primary means for evaluating human behavior in the exclusivist sermon. It is notable that the target of the JUDGEMENT evaluation is also typically external to the preacher and the listeners, i.e. it is also difficult to find any instances of self-oriented admiration, critique, praise or condemnation. Moreover, a significant number of instances of JUDGEMENT evaluation is invoked rather than inherent in the linguistic expression itself (e.g. 12).

(10) That is filthy! That is disgusting, perverted...(11) He was full of wickedness, filth, blasphemy against the Lord Jesus.(12) ... those who come preaching another gospel.

APPRECIATION is rare, relatively speaking, in the exclusivist sermon and almost exclusively limited to the expression of dislike for the Quran or praise for the Bible. Compare the following two descriptions of scripture where it is evident that in the eyes of the preacher "one is a corruption and one is right." 
APPRECIATION of the Quran:

(13) ...the stupidest thing I've ever read

(14) The quality of this book is simply much lower...clearly a man-made concoction APPRECIATION of the (King James) Bible:

(15) ...our wonderful Bible that's just perfect and pure and preserved unto us and it's so powerful

(16) ...how beautiful your Word is Lord.

In terms of DIALOGIC ENGAGEMENT several observations regarding the intertextual and epistemic framing of the sermons can be made. Both sermons rely on explicit references to sources/voices other than the preacher's, i.e. attribution. However, they differ considerably with regard to the external voices allowed to enter the sermon, the extent to which attribution is involved, and how it is implemented. The pluralist preacher draws on a variety of different external voices, but any instance of attributed text is typically confined to a small section of text, and always presented as indirect (paraphrased) speech. Conversely, the exclusivist preacher only relies on two external sources (the Bible and the Quran) and attributions to these sources (particularly the former) are prolific across the whole of the sermon, making the sermon consistently multivoiced: of the opening 600 words of the sermon, 252 words (42\%) are attributable to the Bible. What is more, the preacher standardly quotes the Bible directly with the effect of "surrendering" the discourse to the other voice causing states of affairs to be presented entirely from the point of view of the Biblical voice.

The sermons differ also with respect to epistemic arrangement, with the pluralist preacher being seemingly more inclined to frame his discourse with assertive (e.g. the deontic modal must in (17)) as well as hedging language (e.g. the use of $I$ think, and interrogative mood in (18)).

(17) we must affirm our shared humanity in this world; we must recognize our face within the other ...

(18) but I think it also allows us to have a much deeper discussion: are we responsibly living out our fourth UU principle?

By comparison, the exclusivist preacher shows a strong preference for assertive language (must, obviously, need to, have to etc.), and commonly expresses himself in the imperative mood (19) (a feature that is completely absent in the pluralist sermon).

(19) Notice that this other gospel is contrasted with the grace of Christ. 
To conclude, it is unsurprising that the appraisal analysis of the two sermon samples reveals some marked differences between the pluralist and the exclusivist sermon. What is less obvious, perhaps, is exactly how the preachers' attitudinal preferences and their exploitation of dialogic engagement relates to the preservation of a pluralist and an exclusivist position respectively - this is the central point of the discussion in the next section.

\section{Discussion: Appraisal choices, interreligious positioning, and interpersonal implications}

\subsection{Appraisal implications for pluralist preaching}

The prolific use of AFFECT evaluation in the pluralist sermon helps the preacher to construe a world view where significant appeal is made to emotions and a world internal. This same appeal to emotions is made in several influential definitions of what constitutes interreligious pluralism. Notice e.g., how John Hick, one of the foremost proponents of pluralism, foregrounds the way people should be "fascinated by the manifold differences between the religious traditions, with their different conceptualizations, their different modes of religious experience, and their different forms of individual and social response to the divine."29 Similarly, Knitter notes the "imperative to love one's neighbors" (emphasis added). ${ }^{30} \mathrm{Ap}$ pealing to emotions also individualizes the discourse, firmly grounding the evaluation of states of affairs in the individual evaluator, thereby placing considerable emphasis on the individual herself ("This is my own emotional response to X"). As is evident from Hick's definition, the individual response is held in high regard within pluralist thinking; the individual is seen as a free agent, feeling, behaving and expressing herself in a completely independent way, open to embrace her own religion as well as the religions of others. Thus, it seems that the deployment of AFFECT in this sermon is consistent with and helps the pluralist preacher to address a defining dimension of what it means to be pluralist.

In many ways, the dearth of JUDGEMENT evaluation in the pluralist sermon is unsurprising. In many instances of JUDGEMENT evaluation what is highlighted is a "communal or institutionalized norm of assessment." ${ }^{31}$ Pluralism rejects the claim

29 John Hick, "Religious Pluralism," in Christian Approaches to Other Faiths: A Reader, ed. Paul Hedges and Alan Race (London: SCM Press, 2009), 46.

30 Knitter, Introducing (n. 2), 110.

31 White, "Praising and Blaming” (n. 22), 581. 
that a single set of norms is the solution, making much JUDGEMENT evaluation a non-starter in the first place. What is more, a fundamental question for pluralism is how Christians might engage in dialogue with people of other religions: "you're not really loving another person unless you are ready to listen to them, respect them, and learn from them." ${ }^{32}$ This premise impacts on JUDGEMENT evaluation in two respects. First, if, as Knitter notes, "anything that threatens the mutuality of dialogue [both sides talking, listening and opening themselves up for genuine conversation] is highly suspect, ${ }^{\prime 3}$ then there is an inherent risk involved in using JUDGEMENT evaluation since it targets the other dialoguing individuals and their actions/behavior. In a dialogue that rests on respect (and interpersonal tip toeing), extensive use of JUDGEMENT evaluation has the potential to undermine the mutuality of dialogue. Second, if JUDGEMENT evaluation is used in spite of this risk, positive JUDGEMENT, as that favored by the pluralist preacher in this case study, is more likely to contribute to the dialogue (negative evaluation would be outright counterproductive).

Pluralist communication in the Unitarian Universalist tradition exemplified here is (thus) characterized by the expression of hope, optimism, a generally positive attitude, and a pronounced openness to others. ${ }^{34}$ In terms of the deployment of APPRECIATION evaluation, the analysis showed that the pluralist preacher does make use of positive APPRECIATION to affirm these pluralist characteristics. However, because APPRECIATION, just like JUDGEMENT, involves a precarious projection of an assessment onto an external evaluated entity, even if it is not an individual who may take offense, its use in this pluralist preaching context is fraught with risk, possibly explaining its more restricted use in this sample.

Finally, and turning to DIALOGIC ENGAGEMENT, a precondition for dialogue based on mutuality is the interpersonal acknowledgment of everyone involved (their voices, their values and their beliefs); ${ }^{35}$ this necessitates an expansive dialogic space and an openness to a multitude of different intertextual sources. Importantly, pluralism in the Unitarian Universalist tradition is not about giving up your own faith convictions, nor is it about surrendering to confessional relativism, rather it allows for the possibility to be committed but downplays any competition between religious claims. The pluralist preacher's integration of a variety of sources (from a variety of religious traditions), and his drawing on both assertive and non-assertive language enables a powerful, committed rhetoric that

32 Knitter, Introducing (n. 2), 110.

33 Knitter, Introducing (n. 2), 110.

34 R. Grigg, To Re-Enchant the World: A Philosophy of Unitarian Universalism (Bloomington, IN: XLIBRIS, 2004).

35 Cf. Knitter, Introducing (n. 2), chapter 1. 
simultaneously acknowledges diversity of opinion and opens up a real dialogic space that listeners can inhabit; this is language which indicates genuine engagement rather than mere "tolerance."

\subsection{Appraisal implications for exclusivist preaching}

As noted in Section 3, a central principle of exclusivism, and a very salient theme in the sermon under analysis, is that only Christianity leads to salvation, that "truth is centered in Christianity alone." ${ }^{36}$ This attitude forces negative projection of other religions and, in the case of this exclusivist sermon on Islam, this is manifested primarily in the form of negative JUDGEMENT and, to some lesser extent, negative APPRECIATION. The almost complete lack of affectual evaluation is rhetorically significant since it conveys that any evaluation in this sermon is not grounded in the preacher's individual emotional response to the evaluated entity; rather the evaluation is external, independent from the evaluator, and objectively founded on some communally accepted set of norms for what is admirable/ critical/praiseworthy/condemnable human behavior or a negative or positive quality of some entity. In the context of this sermon, this norm is the Bible, occupying an absolutely central place in this specific evangelical community. Opting for this appraisal "configuration" (preference for JUDGEMENT and APPRECIATION over AFFECT) is equal to the preacher communicating: "What I am saying about X/how I assess X should be accepted by you all, not because I feel this way, but because the Bible tells us so.” Thus, just as the absence of JUDGEMENT and restricted use of APPRECIATION were relevant features in the pluralist sermon to emphasize authority internal to the individual, their presence in the exclusivist sermon serves to construe an inevitable and seemingly external authority (God, Bible, doctrine etc.).

As noted in the analysis, the target of the preacher's (propriety) JUDGEMENT and APPRECIATION is virtually always some dimension of Islam. The picture resulting from this negative evaluation is one which suggests that Islam (it happens to be Islam but the exclusivist position is that any other religion) is a "perverse system of deceit" and that Muslims are doomed, attending as they are to "false prophets" (some form of this term is used 46 times in the sermon). ${ }^{37}$ The almost complete lack of self-oriented JUDGEMENT noted in the analysis is predictable given that exclusivism entails an element of uncritical subjectivity. As Hick notes in his

36 Hedges, Controversies (n. 10), 114.

37 Hedges, Controversies (n. 10), 20. 
critique of this position: for exclusivism “only one's own form of religious experience is an authentic contact with the Transcendent, other forms being delusory." 38

Whereas most instances of JUDGEMENT evaluation are inherent to a word or phrase, making it evaluative across communicative contexts (e.g. sinful), there are also many instances of invoked JUDGEMENT in this sermon (cf. example (19)); an invoked JUDGEMENT reading is conditioned by the context. Invoked JUDGEMENT in this sermon operates against the backdrop of the generally condemning evaluation of Islam but since it is invoked, it requires a shared set of assumptions to be properly decoded as negative by the audience. To this end, invoked JUDGEMENT is rhetorically important as it contributes to preacher-listener rapport and suggests strong "attitudinal alignment." 39

The exclusivist argument evidenced in the sample here restricts the preacher to a form of circular reasoning that does not let him out of the box of exclusivism because his discourse is controlled by judgement of the other as different. In such a context there is understandably little interest in dialogue with other religions (but evangelizing is promoted). This is evident not only from what the preacher is expressing attitudinally ("We should have no fellowship with this wickedness... We need to shine the light of the gospel to them") but also from his dialogic engagement in the sermon. By relying predominantly on assertive language (strong epistemic and deontic modal expression), the preacher can assert biblical truths, speak out of a strong sense of certainty, and provide listeners with directions for how to lead their lives. Effectively this closes down or reduces any dialogic space neither the listeners nor anyone else can occupy the space privileged for Biblical revelation. Similarly, by reducing intertextual influence to a minimum - the Bible only (and the Quran as a blasphemic counter example) - external voices (whatever the source) are not heard in this sermon.

\section{Concluding remarks}

Notwithstanding some obvious limitations - e.g. a failure to reflect the broader panorama of preaching on interreligious themes, and the focus on a single dimension of interreligious identity (appraisal) without considering other variables which invariably influence interreligious positioning - this study has gone some way towards showing the potential for interdisciplinary research to sustain

38 Hick, “Religious Pluralism” (n. 27), 45.

39 White, "Praising and Blaming" (n. 22), 585. 
practically oriented contemporary theology of interreligious dialogue. ${ }^{40}$ If, as Hedges remarks, "interpersonal communication [in interreligious dialogue]...is essential to building cohesion and understanding between communities and individuals, " ${ }^{41}$ then research which highlights the fact that it is through interpersonal positioning/appraisal "that we announce who we are, in social cultural terms" could usefully continue to inform theology of interreligious dialogue.

Engagement with other religions, at whatever level or in whatever form it happens, presupposes an evaluative stance which is a reflection of our interreligious identity and broader moral foundation, as noted by King in laying out her theory of interreligious dialogue: ${ }^{42}$

[...] we all see, think, and cognize from a particular perspective. That is, we never see from a God's-eye point of view, we never think from a neutral place or tabula rasa, but always from a particular point of view rooted in our culture, our language, our worldview and/or religion, and our own individual life experiences.

The contribution of this study is not the way it shows that there is a difference between preaching based in pluralism and preaching based in exclusivism with respect to evaluative construal - that is a predictable finding. Rather, the main merit of this paper is in showing how preachers participating in and facilitating internal interreligious dialogue appropriate an interreligious identity by entering into dynamic "relationships of affiliation or disaffiliation" with the religious other as well as with their audiences, and showing how these relationships are connected to and reflected in preachers' deployment of appraisal and, arguably, in the moral principles of both preachers and listeners. ${ }^{43}$ To this end, future research could fruitfully explore in greater detail how Moral Foundations Theory (referenced only occasionally in this paper) might be adopted to sustain a theory of evaluative construal and interreligious identity along the exclusivist, inclusivist, particularist, and pluralist continuum (thus tapping into a broader spectrum of theological responses to religious Otherness).

Continued research in the area of evaluation in interreligious discourse could also focus on communicative events in interreligious dialogue beyond preaching; this would provide a more comprehensive picture of the power and complexity of multilayered evaluation in the context interreligiousness, and of the connection between evaluative language in action and particular evaluative dispositions/ interreligious positioning during interreligious dialogue.

40 Cf. Moyaert, “Towards” (unpaginated).

41 Hedges, Controversies (n. 10), 13.

42 King, “Interreligious” (n. 4), 107.

43 White, "Praising and Blaming” (n. 22), 590. 